\title{
AN EXAMINATION OF FREE TIME HABITS OF THE ATHLETES IN THE UNIVERSITY KARATE DO TEAM ${ }^{1}$
}

\section{ÜNIVERSITELERIN KARATE DO TAKIMLARINDA YER ALAN SPORCULARIN SERBEST ZAMANLARINI DEĞERLENDİRME ALIŞKANLIKLARININ INCELENMESI}

\author{
Mustafa KARADA $\breve{G}^{1}$, Yüksel SAVUCU ${ }^{2}$, Yonca Süreyya SEZER ${ }^{3}$, Ali Serdar YÜCEL ${ }^{4}$, \\ Serdar ORHAN ${ }^{5}$ Ercan GÜR
}

${ }^{1-6}$ Firat University Faculty of Sports Sciences Elazig / Turkey

ORCID ID: 0000-0002-0299-41981, 0000-0002-2749-6806², 0000-0003-3072-83023 , 0000-0002-4543-41234, 0000-0002-7988-5045 , 0000-0001-6690-828X ${ }^{6}$

Öz: Amaç: Bu araştırmada, üniversitelerin karate do takımlarında yer alan sporcuların serbest zamanlarını değerlendirme alışkanlıklarının incelenmesi amaçlanmıştır. Yöntem: Araştırma evrenini; Elazı̆̆'daki Üniversiteler arası Karate şampiyonasına katılan (37 üniversite, 130 erkek ve 77 kız öğrenci) toplam 207 sporcusu oluşturmaktadır. Araştırmanın örneklemini; araştırmaya katılmak isteyen (89'u erkek 68'i kız öğrenci) toplam 157 sporcu oluşturmaktadır. Araştırmaya katılan bireylerin demografik dağılımlarını belirlemek için yüzde (\%) ve frekans (f) analizleri yapılmıştır. Araştırmada sporcuların serbest zaman tercihlerinin cinsiyet, yaş, doğum yeri ve gelir durumuna göre değişimi incelendi ve $\alpha=0.05$ anlamlılık düzeyinde yapılan ki kare testi uygulandı. Bulgular: Sporcuların yaş değişkenine göre serbest zaman etkinliklerinin bıraktığı etkiler arasındaki farkın $(, 041)$ istatiksel olarak anlamlı olduğu görüldü ( $p>0,05)$. Ayrıca sporcuların gelir düzeyi değişkenine göre; katılma şekli (,041), tercih ettikleri etkinlik şekli (,034), etkinliklerinin tercih edilme nedenleri $(, 000)$ ve etkinliklerinin bıraktığı etkiler $(, 036)$ arasındaki farkın istatistiksel olarak anlamlı olduğu görüldü $(\mathrm{p}>0,05)$. Sonuç: Sporcuların, yaş ve gelir durumu gibi değişsenlerinin sporcuların seçmiş oldukları serbest zamanı değerlendirme türü, şekli, bu etkinlikleri seçme nedeni üzerinde etkisi olduğu görüldü. Ancak sporcuların, cinsiyet ve doğum yeri değişkenine göre istatiksel olarak anlamlı bir sonuca ulaşılamamıştır. Araştırma farklı gruplar üzerinde yapılarak, bireylerin daha etkin bir şekilde serbest zaman aktivitelerine katılmalarına ve bu sürecin iyi yönetilmesine etkisi olabilir.

Anahtar Kelimeler: Serbest Zaman, Rekreasyon, Karate-Do
Abstract: Objective: The purpose of this study is to examine the free time habits of the athletes in the university karate do team. Method: The population of the research consists of a total of 207 athletes ( 37 universities, 130 male and 77 female students) who have participated in the Inter-University Karate Championship in Elazig. The sample of the research consists of 157 athletes ( 89 male and 68 female students). Percentage $(\%)$ and frequency (f) analyses have been performed in order to determine demographic distribution of the participants. Free time preferences of the athletes have been examined according to their gender, age, place of birth and income statuses and chi-square test in 0.05 significance level was applied in the study. Results: It has been seen that there is statistically a significant difference (.041) relating to the effects of free time events depending on the age variable of the athletes $(\mathrm{p}<0.05)$. Moreover, it has been observed that there is a statistically significant difference among participation type (.041), the preferred activity type $(.034)$, reasons for the preferences of the activities $(.000)$ and the effects of the activities (.036) $(\mathrm{p}<0.05)$. Conclusion: It has been found out that some variables such as age and income status have some effects on the reason of athletes' preferring evaluation type and method of free times. However, there is not a statistically significant difference according to ages and places of birth of the athletes. Conducting the research on different groups may make individuals lean to free-time activities more efficiently and have an effect on better management of this process.

Key Words: Free Time, Recreation, Karate-Do

Doi: $10.17363 / S S T B .2017 .4 .3$

(1) Corresponding Author: A. Serdar YÜCEL, Firat University, Faculty of Sports Sciences, Elazig / Turkey, alsetu_23@ hotmail.com, Received: 11.08.2017, Accepted: 12.12.2017, Type ofarticle (Research-Application) Conflict of Interest: None / "None of Ethics Committee" 


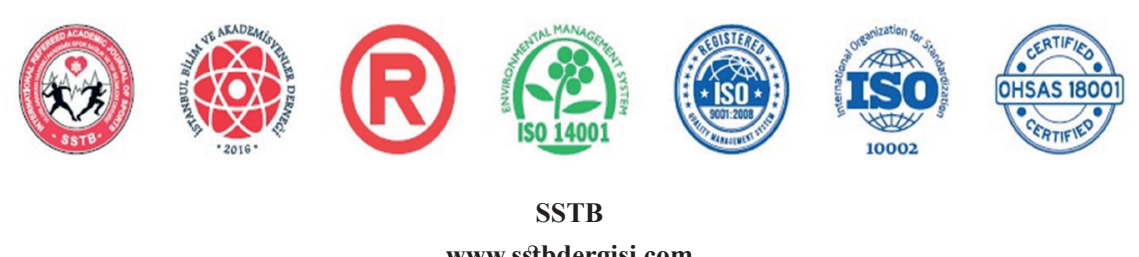

www.sstbdergisi.com

International Refereed Academic Journal of Sports, Health and Medical Sciences

October - November - December Issue 25 Autumn Winter Season Year: 2017

JEL CODE: A220-M490 ID:355 K:129

ISSN Print: 2146-8508 Online 2147-1711

(ISO 18001-OH-0090-13001706 / ISO 14001-EM-0090-13001706 / ISO 9001-QM-0090-13001706 / ISO 10002-CM-0090-13001706)

(TRADEMARK)

(2015/04315- 2015-GE-18972)

\section{INTRODUCTION}

Social and mental development as well as physical development accompany to each sports branch due to the fact that young generations learn collective working through sports activities. In addition, the gate of friendship and socialization is also opened (K1z1lkaya, 2009'den akt: Kanat vd., 2013: 461; Kırımoğlu vd., 2010: 103). Particularly, athletes consolidate their sense of socialization in their free times and they turn competitive environment into a more socialized place.

Tezcan defines free time as the time remaining after all compulsory liabilities are performed regarding job, life and other duties and in which the individual has the right to use freely. Free time is described as "the time in which an individual gets rid of all difficulties or connections concerning both the individual herself/himself and the others and in which she/he engages in an activity chosen willingly" (Tezcan, 1982: 10).

According to Parker, free time is a period in which an individual gets rid of all difficulties or connections concerning both the individual herself/himself and the others and in which she/he engages in an activity chosen willingly (Tezcan, 1994'den aktaran: Güngörmüş vd., 2006: 655).

Free time audits remain ordinary and within the borders of some stereotypes when free time trainings are insufficient and when stable, constructive, creative organization and traditions are not adopted and where this culture does not become efficient regarding free time. It is necessary for an individual to see free time as a way of elevation. There, the individual proceeds by realizing herself/himself and that is the thing that should be learned (Erdemli, 2002: 50).

There are also some views that it is not needed to have/receive a special training to how to utilize free time; this happens spontaneously, it is a free time and the individual does whatever she/he wants. This kind of view expresses evaluating and utilizing free time wrongly. Traditionally, free time training can be seen as learning information and skills. This training enables use of free time programs efficiently and it also takes place within non-formal training. It is the aim of free time training to benefit from free time constructively and wisely (Tezcan, 1994: 76'dan aktaran: Ağaoğlu vd., 2006: 315).

In the $20^{\text {th }}$ century, many factors forced free time training to change in terms of purpose and function. Human rights, developments in science and technology and alterations in the socio-economic status of the society caused increase in the expectation from training and it forced free time training to change in favor of individuals by suppressing the traditional training. Free time training composes a sig- 


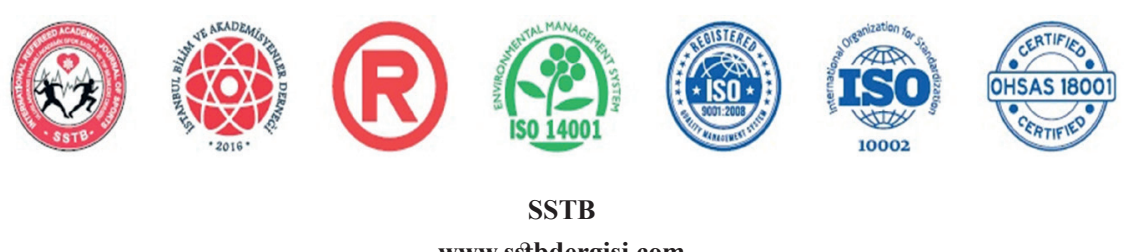

www.sstbdergisi.com

International Refereed Academic Journal of Sports, Health and Medical Sciences

October - November - December Issue 25 Autumn Winter Season Year: 2017

JEL CODE: A220-M490 ID:355 K:129

ISSN Print: 2146-8508 Online 2147-1711

(ISO 18001-OH-0090-13001706 / ISO 14001-EM-0090-13001706 / ISO 9001-QM-0090-13001706 / ISO 10002-CM-0090-13001706) (TRADEMARK)

(2015/04315- 2015-GE-18972)

nificant element within changing training manner. At the same time, it also supports training directly or indirectly except for the formal training. Free time training takes an important place in the functionality of training process (Torkildsen, 1992: 25).

According to Karaküçük, recreation is called the activities carried out individually or with a group of friends willingly and voluntarily within the independent and disconnected free time remaining from working and other compulsory tasks in order to enable personal satisfaction, to get pleasure, to regain, protect or maintain mental and physical health which is affected or imperiled from routine life style or negative environmental factors as well as intensive working load. In modern terms, recreation as a social institution, accumulation of information and a professional working area is a full and happy life tool which meets many needs of an individual and which is precious within itself independent from work. (Karaküçük, 2001: 55-60).

On the other hand, karate is derived from the words "kara" meaning empty and "te" meaning hand and associated with unarmed hand. "Kara" is also expressed as "the space whose end is not seen". At first, "tô was called as "de" meaning hand (hands of China) in China. Then, the term 'Okinawa te' (hands of Okinawa) and in the latter definition the term 'Karate jutsu' was used. Here, "karate” was used as karate and "jutsu" was used as technique which means the technique of karate together. In its latest form, it means "empty, unarmed hand". Hand is the symbol of productivity in Far Eastern cultures like in many cultures of the world. As its opposite meaning, punch is the symbol of power and conflict while open hand is accepted as the sign of productivity, virtue, peace and friendship (for example Ying Yang). In short, karate, that is, "open hand" can be described as peaceful move in which the phenomenon of goodwill becomes prominent. Karate-do is divided into two as traditional and sport karate within itself. The traditional karate-do is an individual improvement path within the efforts of individual's becoming the best. At the same time, it reveals the skills of controlling one's ego instead of competitiveness and rivalry perception. However, sport karate possesses modern sports understanding getting its origins from karate-do, but proceeding with the ideal of Olympic soul. Competitions in sport karate are performed within universal and international sportive rules based on the understanding of evaluating physical skills with specific provisions. It emphasizes the fight of phenomenon with only the ego within the individual as well as the endeavor to be respectful and fair towards the self, environment and living nature. ${ }^{1}$

1 (http://www.karate.gov.tr, 01.07.2016). 


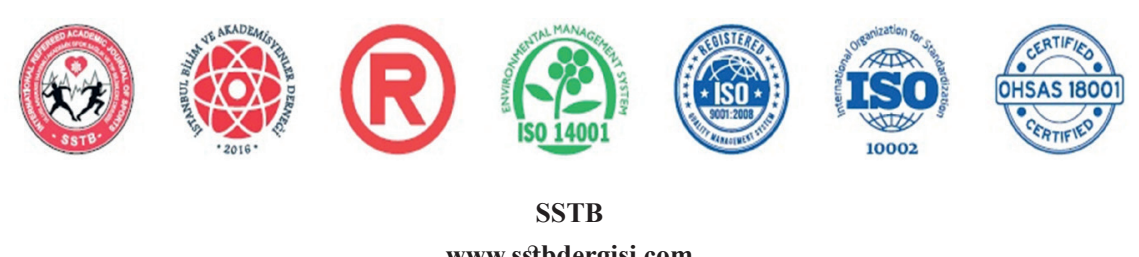

www.sstbdergisi.com

International Refereed Academic Journal of Sports, Health and Medical Sciences

October - November - December Issue 25 Autumn Winter Season Year: 2017

JEL CODE: A220-M490 ID:355 K:129

ISSN Print: 2146-8508 Online 2147-1711

(ISO 18001-OH-0090-13001706 / ISO 14001-EM-0090-13001706 / ISO 9001-QM-0090-13001706 / ISO 10002-CM-0090-13001706) (TRADEMARK)

(2015/04315- 2015-GE-18972)

Universities are the places where individuals form their free time activities for their future life. The habits acquired in this period show their effects in the future life of individuals. In our study, it was aimed at determining free time habits of the athletes studying in universities and performing karate-do, and then examining whether they differ according to different demographical features.

\section{MATERIAL and METHOD}

\section{Population of the Research}

The population of the research consists of a total of 207 athletes 130 of whom are male and 77 of whom are female students who participated in the Inter-University Karate Championship in Elazig.

\section{Sample of the Research}

The sample of the research consists of 157 athletes 89 of whom are male and 68 of whom are female students.

\section{Research Method}

The questionnaire applied by Y1lmaz (2011) was used in the research. SPSS 21 statistical packet program was used for arranging the data. Percentage (\%) and frequency (f) analyses were carried out in order to determine demographical features of the participants. The difference between free time habits of the athletes and their gender, place of birth and income status was examined and the significance level $(p<0.05)$ between those differences were determined by Chi-Square test.

\section{Research Group}

Study group of the research consists of a total of 207 athletes 130 of whom are male and 77 of whom are female students from 37 universities who participated in the Inter-University Karate Championship in Elazig between 27 and 29 April 2016. Questionnaire was conducted on the study group and the free time activities of university students who were engaged in karate-do and the types of attending those activities were examined.

\section{Significance of the Research}

In the research, it is deemed significant to determine the participation rate of the athletes studying in universities and performing karate-do in their free time activities and to examine the effect of participation to free time activities on their education life.

Universities are the places where individuals form their free time activities for their future life. The habits acquired in this period affect the individual's future life, as well. The studies to be conducted on the athletes engaged in karate sports will determine socializing levels of these individuals and reveal the contributions of this sports branch on the development of the individuals. 


\section{(2)

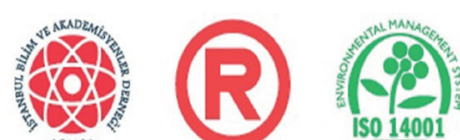 \\ SSTB \\ www.sstbdergisi.com}

International Refereed Academic Journal of Sports, Health and Medical Sciences

October - November - December Issue 25 Autumn Winter Season Year: 2017

JEL CODE: A220-M490 ID:355 K:129

ISSN Print: 2146-8508 Online 2147-1711

(ISO 18001-OH-0090-13001706 / ISO 14001-EM-0090-13001706 / ISO 9001-QM-0090-13001706 / ISO 10002-CM-0090-13001706)

(TRADEMARK)

(2015/04315- 2015-GE-18972)

\section{Aim of the Research}

This research aimed at determining free time habits of athletes studying in universities and performing karate-do, and then examining whether they differ according to different demographical features.

\section{Table 1. Universities and Number of Athletes Participating in Karate Do Championship}

\begin{tabular}{|c|c|c|c|c|}
\hline Sira No & Participating Universities & Female Athlete & Male Athlete & Total \\
\hline 1 & Ahi Evran University & & 6 & 6 \\
\hline 2 & Akdeniz University & 1 & 2 & 3 \\
\hline 3 & Ankara University & 2 & 7 & 9 \\
\hline 4 & Bartın University & 9 & 7 & 16 \\
\hline 5 & Başkent University & & 1 & 1 \\
\hline 6 & Celal Bayar University & 5 & 4 & 9 \\
\hline 7 & Çukurova University & 5 & 7 & 12 \\
\hline 8 & Düzce University & 7 & 10 & 17 \\
\hline 9 & Gazi University & 3 & 5 & 8 \\
\hline 10 & Hacettepe University & & 1 & 1 \\
\hline 11 & İskenderun Technical University & & 1 & 1 \\
\hline 12 & İstanbul Aydın University & 5 & 9 & 14 \\
\hline 13 & İstanbul Işık University & 1 & & 1 \\
\hline 14 & İstanbul Medipol University & 1 & & 1 \\
\hline 15 & İstanbul Commerce University & 3 & 4 & 7 \\
\hline 16 & İzmir University & & 1 & 1 \\
\hline 17 & Karamanoğlu Mehmet Bey University & 1 & 1 & 2 \\
\hline 18 & Marmara University & 4 & 7 & 11 \\
\hline 19 & Mersin University & 1 & & 1 \\
\hline 20 & Mustafa Kemal University & 3 & 5 & 8 \\
\hline 21 & Middle East Technical University & 3 & 2 & 5 \\
\hline 22 & Pamukkale University & 4 & 5 & 9 \\
\hline 23 & Sabancı University & & 2 & 2 \\
\hline 24 & Süleyman Demirel University & 3 & 5 & 8 \\
\hline
\end{tabular}




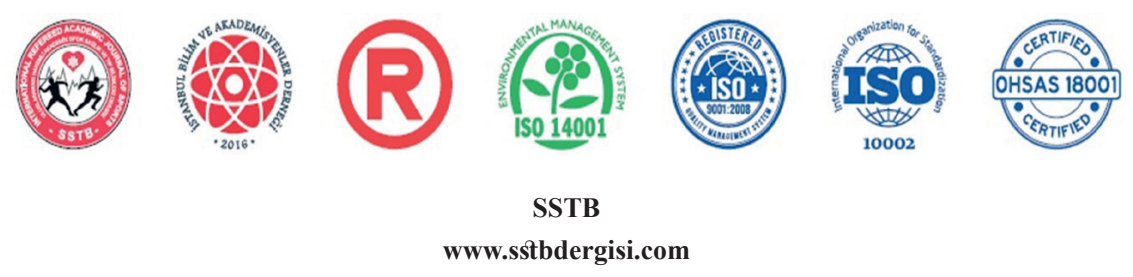

International Refereed Academic Journal of Sports, Health and Medical Sciences

October - November - December Issue 25 Autumn Winter Season Year: 2017

JEL CODE: A220-M490 ID:355 K:129

ISSN Print: 2146-8508 Online 2147-1711

(ISO 18001-OH-0090-13001706 / ISO 14001-EM-0090-13001706 / ISO 9001-QM-0090-13001706 / ISO 10002-CM-0090-13001706) (TRADEMARK)

(2015/04315- 2015-GE-18972)

\begin{tabular}{|c|c|c|c|c|}
\hline 25 & Uludağ University & & 3 & 3 \\
\hline 26 & Trakya University & 5 & 7 & 12 \\
\hline 27 & Firat University & 2 & 7 & 9 \\
\hline 28 & Anadolu University & 2 & 1 & 3 \\
\hline 29 & Afyon Kocatepe University & 1 & & 1 \\
\hline 30 & Abant İzzet Baysal University & 4 & & 4 \\
\hline 31 & Gaziosmanpaşa University & 2 & 1 & 3 \\
\hline 32 & Atatürk University & & 6 & 6 \\
\hline 33 & Zirve University & & 1 & 1 \\
\hline 34 & Balıkesir University & & 7 & 7 \\
\hline 35 & Muş Alparslan University & & 1 & 1 \\
\hline 36 & Dumlupınar University & & 3 & 3 \\
\hline 37 & Bayburt University & & 1 & 1 \\
\hline \multicolumn{2}{|c|}{ Grand Total } & 77 & 130 & 207 \\
\hline
\end{tabular}




\section{(2)
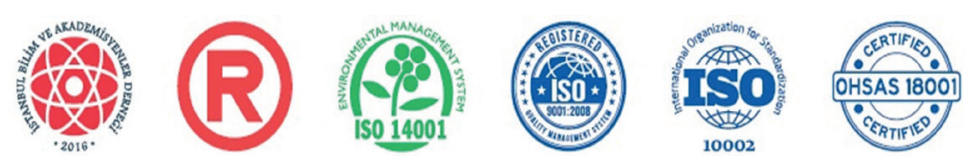 \\ SSTB \\ www.sstbdergisi.com}

International Refereed Academic Journal of Sports, Health and Medical Sciences

October - November - December Issue 25 Autumn Winter Season Year: 2017

JEL CODE: A220-M490 ID:355 K:129

ISSN Print: 2146-8508 Online 2147-1711

(ISO 18001-OH-0090-13001706 / ISO 14001-EM-0090-13001706 / ISO 9001-QM-0090-13001706 / ISO 10002-CM-0090-13001706) (TRADEMARK)

(2015/04315- 2015-GE-18972)

\section{RESULTS}

Table 2. Demographical Variables

\begin{tabular}{|c|c|c|c|}
\hline \multicolumn{2}{|c|}{ VARIABLES } & $\mathbf{N}$ & $\%$ \\
\hline \multirow{2}{*}{ Gender } & Male & 89 & 56.7 \\
\hline & Female & 68 & 43.3 \\
\hline \multirow{4}{*}{ Age } & 20 years old and below & 33 & 21.0 \\
\hline & Between 21 and 22 years old & 60 & 38.2 \\
\hline & Between 23 and 24 years old & 45 & 28.7 \\
\hline & 25 years old and above & 19 & 12.1 \\
\hline \multirow{5}{*}{ Place of Birth } & Village & 14 & 8.9 \\
\hline & Town & 20 & 12.7 \\
\hline & City & 75 & 47.8 \\
\hline & Municipality & 46 & 29.3 \\
\hline & Abroad & 2 & 1.3 \\
\hline \multirow{4}{*}{ Monthly Income } & Between $550 \mathrm{TL}$ and $1000 \mathrm{TL}$ & 3 & 1.9 \\
\hline & Between 1001 TL and 2000 TL & 64 & 40.8 \\
\hline & Between $2001 \mathrm{TL}$ and $3000 \mathrm{TL}$ & 56 & 35.7 \\
\hline & 3001 TL and over & 34 & 21.7 \\
\hline
\end{tabular}

When the distribution of participant students is examined according to their gender, it is seen that $56.7 \%$ of them (89 individuals) are men and $43.3 \%$ of them (68 individuals) are women. Most of the participants are composed of male university students.

When the distribution of participant university students is (özne distribution değil mi? O zaman tekil olmalı) examined according to their ages, it is seen that $21.0 \%$ of them (33 individuals) are below 20 years old, 38.2\% of them (60 individuals) are between 21 and
22 years old, $28.7 \%$ of them (45 individuals) are between 23 and 24 years old and 12.1\% of them (19 individuals) are 25 years old and above. Most of the participants are between 21 and 22 years old.

When the distribution of participant university students is examined according to their places of birth, it is seen that $29.3 \%$ of them (46 individuals) were born in municipalities, $47.8 \%$ of them (75 individuals) were born in cities, $12.7 \%$ of them (20 individuals) were born in towns, $8.9 \%$ of them (14 individuals) 
International Refereed Academic Journal of Sports, Health and Medical Sciences

October - November - December Issue 25 Autumn Winter Season Year: 2017

JEL CODE: A220-M490 ID:355 K:129

ISSN Print: 2146-8508 Online 2147-1711

(ISO 18001-OH-0090-13001706 / ISO 14001-EM-0090-13001706 / ISO 9001-QM-0090-13001706 / ISO 10002-CM-0090-13001706)

(TRADEMARK)

(2015/04315- 2015-GE-18972)

were born in villages and $1.3 \%$ of them were born abroad. It is observed that most of the participants were born in cities.

As seen in the Table, $1.9 \%$ (3 individuals) of the participants' monthly income is between
$550 \mathrm{TL}$ and $1000 \mathrm{TL}, 40.8 \%$ (64 individuals) of them is between 1001 and 2000 TL, $35.7 \%$ (56 individuals) of them is between 2001 and $3000 \mathrm{TL}$, and $21.7 \%$ of them is over 3000 . It is seen that most of the participants' income level is between $1001 \mathrm{TL}$ and 2000 TL.

Table 3. Utilizing Free Time

\begin{tabular}{|c|c|c|c|}
\hline \multicolumn{2}{|r|}{ Variables } & \multirow{2}{*}{$\frac{\mathbf{N}}{23}$} & \multirow{2}{*}{$\begin{array}{c}\% \\
14.6\end{array}$} \\
\hline \multirow{4}{*}{$\begin{array}{l}\text { 3.1. Specify your } \\
\text { participation type to } \\
\text { free time activities in } \\
\text { general terms. }\end{array}$} & Generally alone & & \\
\hline & Generally with my family & 33 & 21.0 \\
\hline & Generally with my friends & 99 & 63.1 \\
\hline & Generally under the guidance of specialists & 2 & 1.3 \\
\hline \multirow{6}{*}{$\begin{array}{l}\text { 3.2. How much time } \\
\text { do you allocate to } \\
\text { yourself after the daily } \\
\text { compulsory duties? }\end{array}$} & None & 6 & 3.8 \\
\hline & 1-2 hours & 47 & 29.9 \\
\hline & 3-4 hours & 40 & 25.5 \\
\hline & 5-6 hours & 26 & 16.6 \\
\hline & $7-8$ hours & 10 & 6.4 \\
\hline & More than 8 hours & 28 & 17.8 \\
\hline \multirow{5}{*}{$\begin{array}{l}\text { 3.3. Which of the } \\
\text { following activities do } \\
\text { you generally prefer in } \\
\text { your free times? }\end{array}$} & I generally go to the cinema and theatre & 16 & 10.2 \\
\hline & I generally go out for market, bazaar, fair, park, etc. & 43 & 27.4 \\
\hline & I generally play sports & 85 & 54.1 \\
\hline & I am generally engaged in handicraft and art requiring skill & 10 & 6.4 \\
\hline & $\begin{array}{l}\text { I generally participate in the activities of NGOs and } \\
\text { associations }\end{array}$ & 3 & 1.9 \\
\hline \multirow{5}{*}{$\begin{array}{l}\text { 3.4. What are the } \\
\text { reasons of choosing } \\
\text { free time activities? }\end{array}$} & $\begin{array}{l}\text { Because they are suitable for my skills and they make me } \\
\text { adopt habit }\end{array}$ & 39 & 24.8 \\
\hline & $\begin{array}{l}\text { For staying away from work environment and acquire a } \\
\text { social environment }\end{array}$ & 78 & 49.7 \\
\hline & $\begin{array}{l}\text { Because the facilities, tools and devices regarding the activity I } \\
\text { demand are sufficient }\end{array}$ & 29 & 18.5 \\
\hline & For health reasons & 8 & 5.1 \\
\hline & Because it does not necessitate to spend much money & 3 & 1.9 \\
\hline
\end{tabular}




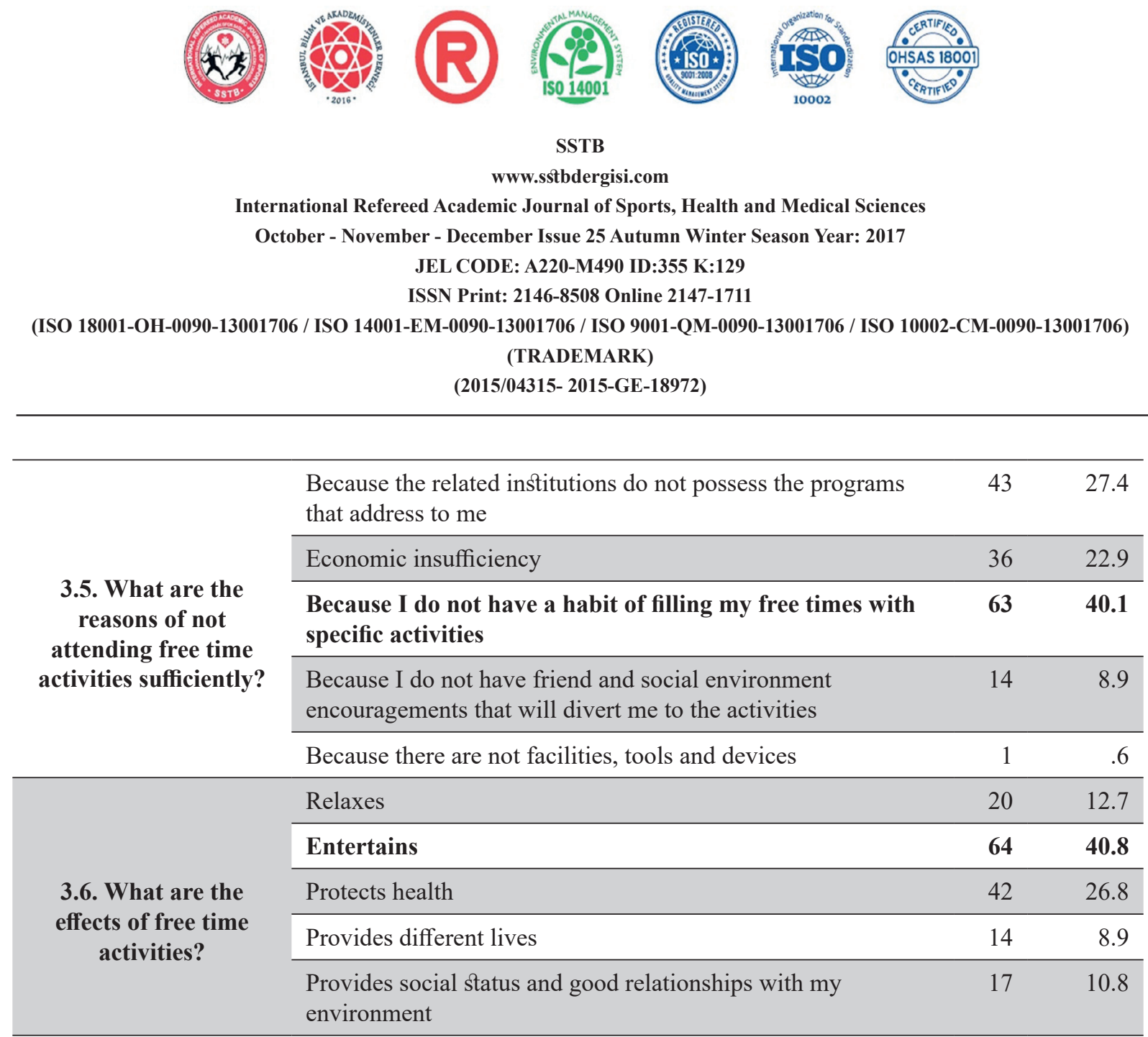

When the participation types of university students in free time activities are examined, it is seen that $63.1 \%$ (99 individuals) of the athletes participate in free time activities with their friends and $21.0 \%$ (33 individuals) of them with their family. Most of the participants usually spend their free time activities with their friends.

When the time allocated for daily free time activities of the participants is examined, it is seen that $29.9 \%$ of them (47 individuals) spend 1-2 hours; $25, . \%$ of them (40 individuals) spend 3-4 hours; $17.8 \%$ of them (28 individuals) spend more than 8 hours, $16.6 \%$ of them (26 individuals) spend 5-6 hours, 6.4\% of them (10 individuals) spend 7-8 hours and $3.8 \%$ of them (6 individuals) spend no time on these activities. It is observed that most of the participants allocate time for free time activities between 1-2 hours and 3-4 hours.

When the mostly preferred free time activities of university students are examined, it is seen that $54.1 \%$ of them generally play sports, $27.4 \%$ of them generally go out for market, bazaar, fair, park, etc., $10.2 \%$ of them generally go to the cinema and theatre, $6.4 \%$ of them generally engage in handicraft and art requiring skill, $1.9 \%$ of them generally participate in the activities of NGOs and associations. It is observed that most of the participants prefer playing sports in their free times.

When the reasons of choosing free time activities of the participants are examined, it is seen that $49.7 \%$ of them choose free time activities for staying away from work environment and acquire a social environment, 


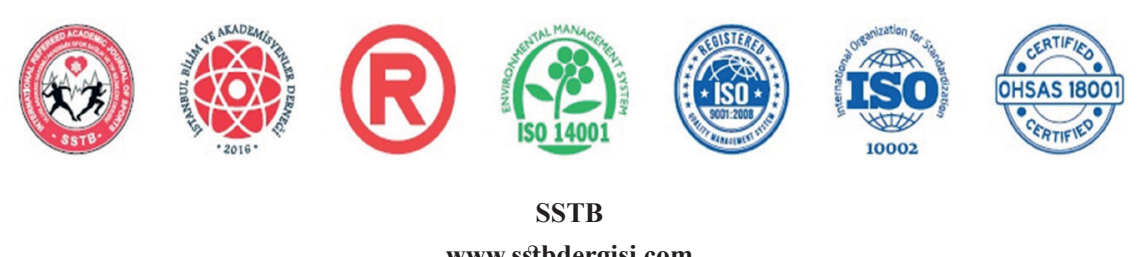

www.sstbdergisi.com

International Refereed Academic Journal of Sports, Health and Medical Sciences

October - November - December Issue 25 Autumn Winter Season Year: 2017

JEL CODE: A220-M490 ID:355 K:129

ISSN Print: 2146-8508 Online 2147-1711

(ISO 18001-OH-0090-13001706 / ISO 14001-EM-0090-13001706 / ISO 9001-QM-0090-13001706 / ISO 10002-CM-0090-13001706)

(TRADEMARK)

(2015/04315- 2015-GE-18972)

$24.8 \%$ of them for being suitable for their skills and they make them adopt habit, $18.5 \%$ of them for the fact that the facilities, tools and devices regarding the activity they demand are sufficient, $5.1 \%$ of them for health reasons, $1.9 \%$ of them for the fact that they do not necessitate to spend much money. It is observed that among the reasons of preferring free time activities, most of the participants choose staying away from work environment and acquire a social environment.

When the reasons of participant university students' not attending free time activities sufficiently are examined, it is seen that $40.1 \%$ of the participants do not have a habit of filling their free times with specific activities, $27.4 \%$ of them specify that the related institutions do not possess the programs that address to them, $22.9 \%$ of them do not attend because of economic insufficiency, $8.9 \%$ of them do not have friend and social environment encouragements that will divert them to the activities, .6\% of them specify that there are not facilities, tools and devices. It is observed that among the reasons of not attending free time activities sufficiently, most of the participants choose not having a habit of filling their free times with specific activities.

When the effects of free time activities on participant university students are examined, it is seen that $40.8 \%$ of the participants think that the activities are entertaining, $26.8 \%$ of them think they protect health, $12.7 \%$ of them think they provide social status and good relationships with their environment, $8.9 \%$ of them think they provide different lives. It is observed that among the effects of free time activities on the participants, most of the participants choose the entertaining item. 


\section{$\left(x^{\circ}\right)$

International Refereed Academic Journal of Sports, Health and Medical Sciences

October - November - December Issue 25 Autumn Winter Season Year: 2017

JEL CODE: A220-M490 ID:355 K:129

ISSN Print: 2146-8508 Online 2147-1711

(ISO 18001-OH-0090-13001706 / ISO 14001-EM-0090-13001706 / ISO 9001-QM-0090-13001706 / ISO 10002-CM-0090-13001706) (TRADEMARK)

(2015/04315- 2015-GE-18972)

Table 4. The Effects of Free Time Activities on the University Students Engaged in Karate Do Sports according to Age

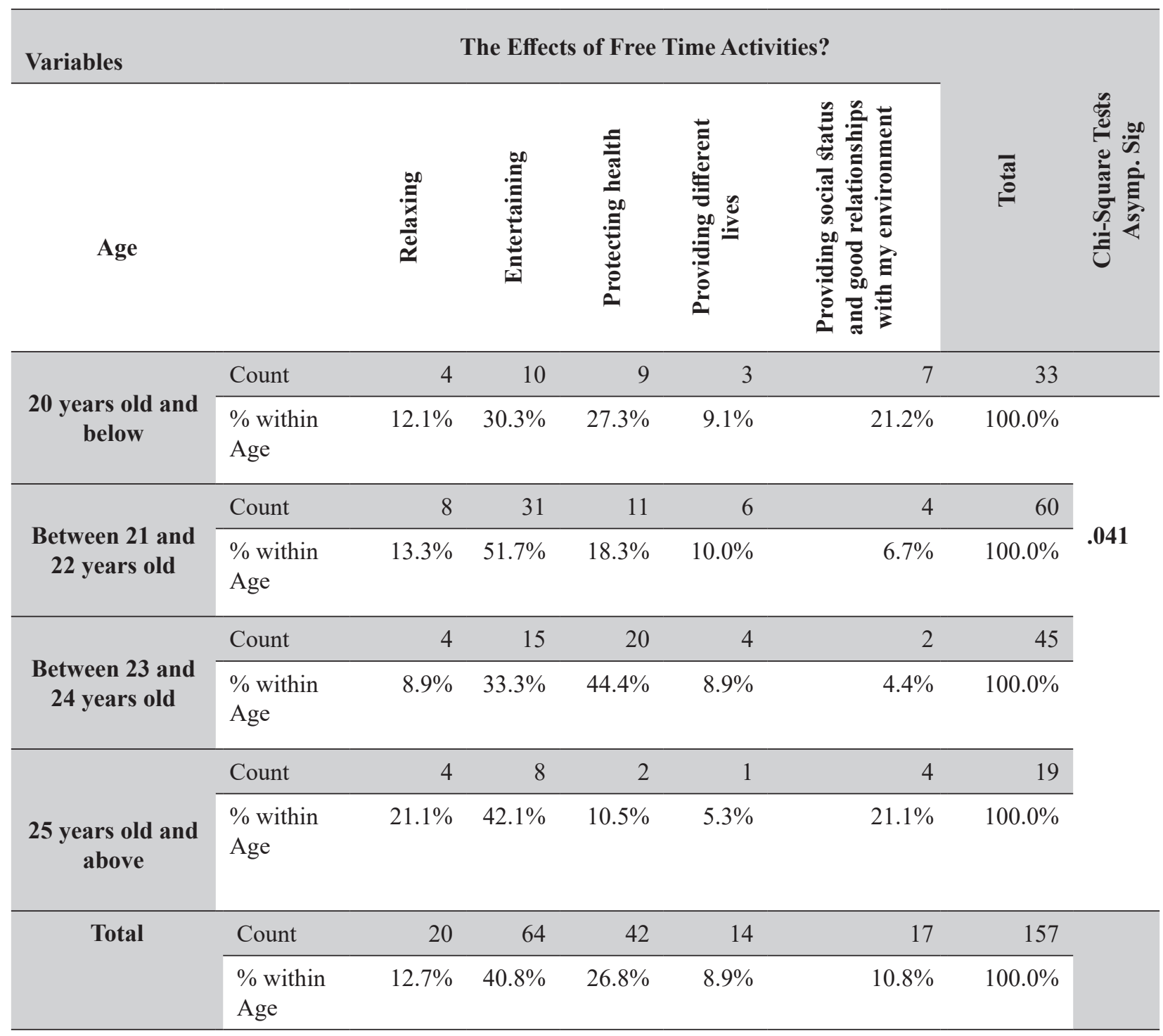

$\mathrm{p}<0.05$

When Table 4 is examined, it has been determined whether there is a significant difference among the views of athletes regarding the effects of free time activities and Chi-
Square analysis has been conducted depending on the answers of the athletes according to age factor of the students. Analysis results have showed that there is a significant difference among the effects of free time activities 


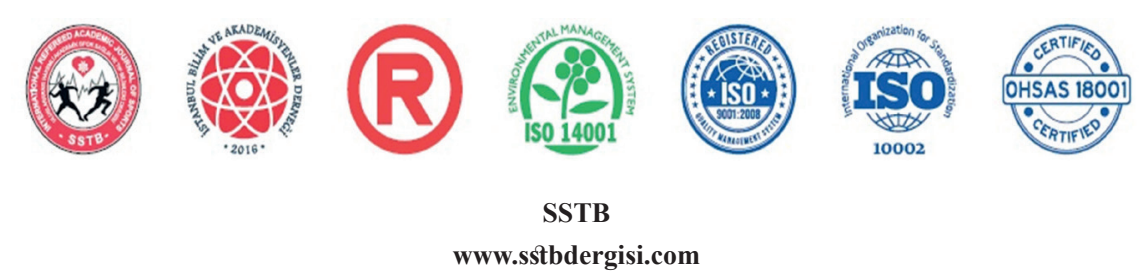

International Refereed Academic Journal of Sports, Health and Medical Sciences

October - November - December Issue 25 Autumn Winter Season Year: 2017

JEL CODE: A220-M490 ID:355 K:129

ISSN Print: 2146-8508 Online 2147-1711

(ISO 18001-OH-0090-13001706 / ISO 14001-EM-0090-13001706 / ISO 9001-QM-0090-13001706 / ISO 10002-CM-0090-13001706)

(TRADEMARK)

(2015/04315- 2015-GE-18972)

according to age factors of the athletes. When a statistically significant difference has been the questions responded by the athletes ac- determined $(p<0.05)$.

cording to age variable have been examined,

Table 5. General Participation Types of University Students Engaged in Karate Do Sports to Free Time Activities According to Monthly Income

\begin{tabular}{|c|c|c|c|c|c|c|c|}
\hline \multicolumn{2}{|l|}{ Variables } & \multicolumn{4}{|c|}{$\begin{array}{l}\text { Specify your participation type to free time activi- } \\
\text { ties in general terms }\end{array}$} & \multirow[t]{2}{*}{ Total } & \multirow{2}{*}{$\begin{array}{l}\text { Chi-Square } \\
\text { Tests } \\
\text { Asymp. Sig }\end{array}$} \\
\hline Monthly income & & 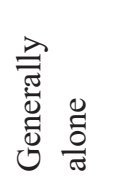 & 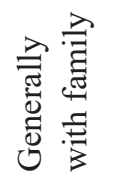 & 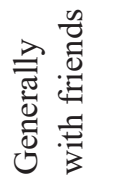 & 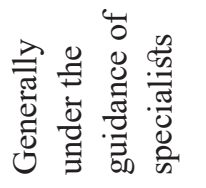 & & \\
\hline \multirow{2}{*}{$\begin{array}{l}\text { Between } 550 \mathrm{tl} \\
\text { and } 1000 \mathrm{tl}\end{array}$} & Count & 2 & 1 & 0 & 0 & 3 & \\
\hline & $\begin{array}{l}\% \text { within } \\
\text { monthly } \\
\text { income }\end{array}$ & $66.7 \%$ & $33.3 \%$ & $.0 \%$ & $.0 \%$ & $100.0 \%$ & \multirow[t]{6}{*}{.041} \\
\hline \multirow[b]{2}{*}{$\begin{array}{l}\text { Between } 1001 \mathrm{tl} \\
\text { and } 2000 \mathrm{tl}\end{array}$} & Count & 11 & 14 & 39 & 0 & 64 & \\
\hline & $\begin{array}{l}\text { \% within } \\
\text { monthly } \\
\text { income }\end{array}$ & $17.2 \%$ & $21.9 \%$ & $60.9 \%$ & $.0 \%$ & $100.0 \%$ & \\
\hline \multirow[b]{2}{*}{$\begin{array}{l}\text { Between } 2001 \\
\text { and } 3000 \mathrm{tl}\end{array}$} & Count & 8 & 12 & 36 & 0 & 56 & \\
\hline & $\begin{array}{l}\text { \% within } \\
\text { monthly } \\
\text { income }\end{array}$ & $14.3 \%$ & $21.4 \%$ & $64.3 \%$ & $.0 \%$ & $100.0 \%$ & \\
\hline \multirow[b]{2}{*}{$\begin{array}{l}3001 \text { tl and } \\
\text { higher }\end{array}$} & Count & 2 & 6 & 24 & 2 & 34 & \\
\hline & $\begin{array}{l}\% \text { within } \\
\text { monthly } \\
\text { income }\end{array}$ & $5.9 \%$ & $17.6 \%$ & $70.6 \%$ & $5.9 \%$ & $100.0 \%$ & \\
\hline \multirow[b]{2}{*}{ Total } & Count & 23 & 33 & 99 & 2 & 157 & \\
\hline & $\begin{array}{l}\text { \% within } \\
\text { monthly } \\
\text { income }\end{array}$ & $14.6 \%$ & $21.0 \%$ & $63.1 \%$ & $1.3 \%$ & $100.0 \%$ & \\
\hline
\end{tabular}

$\mathrm{p}<0.05$ 


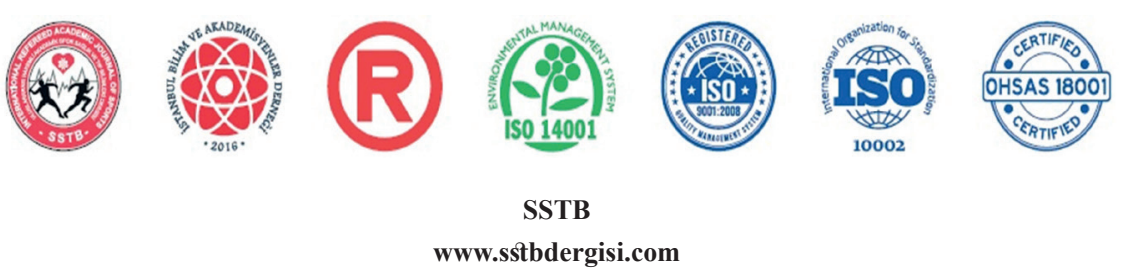

International Refereed Academic Journal of Sports, Health and Medical Sciences

October - November - December Issue 25 Autumn Winter Season Year: 2017

JEL CODE: A220-M490 ID:355 K:129

ISSN Print: 2146-8508 Online 2147-1711

(ISO 18001-OH-0090-13001706 / ISO 14001-EM-0090-13001706 / ISO 9001-QM-0090-13001706 / ISO 10002-CM-0090-13001706) (TRADEMARK)

(2015/04315- 2015-GE-18972)

When Table 5 is examined, it is determined whether there is a significant difference among the views of athletes regarding participation type to free time activities in general terms and Chi-Square analysis has been conducted depending on the answers of the athletes according to monthly income variable of the students. Analysis results have showed that there is a significant difference among participation type to free time activities in general terms according to monthly income variable of the athletes. When the questions responded by the athletes according to monthly income variable of the athletes is examined, a statistically significant difference has been found $(p<0.05)$. 


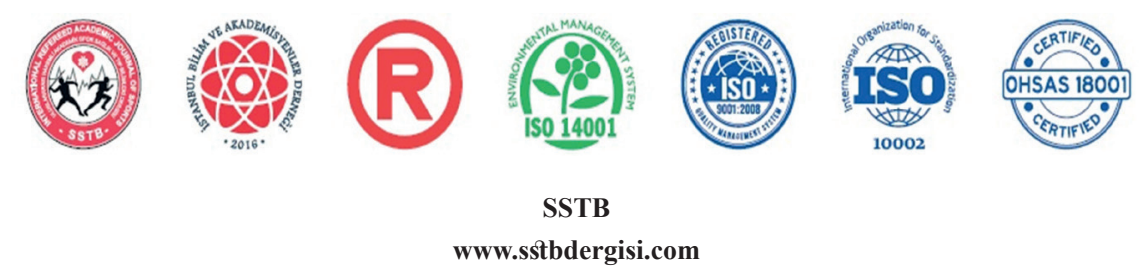

International Refereed Academic Journal of Sports, Health and Medical Sciences

October - November - December Issue 25 Autumn Winter Season Year: 2017

JEL CODE: A220-M490 ID:355 K:129

ISSN Print: 2146-8508 Online 2147-1711

(ISO 18001-OH-0090-13001706 / ISO 14001-EM-0090-13001706 / ISO 9001-QM-0090-13001706 / ISO 10002-CM-0090-13001706)

(TRADEMARK)

(2015/04315- 2015-GE-18972)

Table 6. The Preferred Free Time Activities by the University Students Engaged in Karate Do Sports According to Monthly Incomes of the Athletes

\begin{tabular}{|c|c|c|c|c|c|c|c|c|}
\hline \multirow{2}{*}{$\begin{array}{l}\text { Variables } \\
\begin{array}{l}\text { Monthly } \\
\text { income }\end{array}\end{array}$} & & \multicolumn{5}{|c|}{$\begin{array}{l}\text { Which of the following activities do you generally prefer in } \\
\text { your free times? }\end{array}$} & \multirow[b]{2}{*}{ 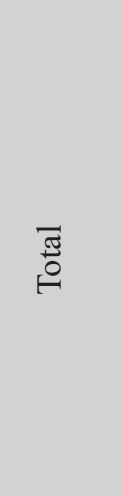 } & \multirow[b]{2}{*}{ 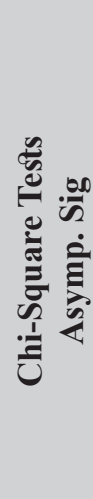 } \\
\hline & & 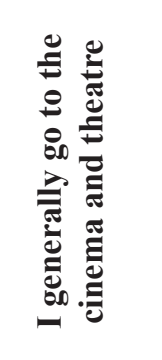 & 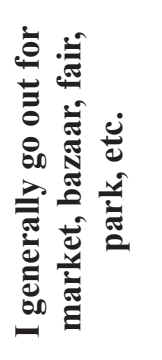 & 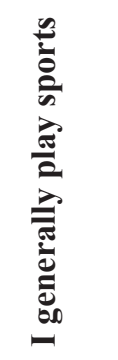 & 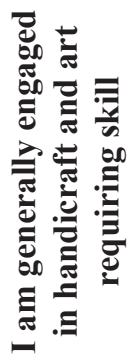 & 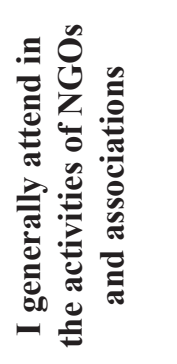 & & \\
\hline \multirow{2}{*}{$\begin{array}{l}\text { Between } \\
550 \text { tl and } \\
1000 \text { tl }\end{array}$} & Count & 0 & 0 & 2 & 0 & 1 & 3 & \multirow{8}{*}{.034} \\
\hline & $\begin{array}{l}\text { \% within } \\
\text { monthly } \\
\text { income }\end{array}$ & $.0 \%$ & $.0 \%$ & $66.7 \%$ & $.0 \%$ & $33.3 \%$ & $100.0 \%$ & \\
\hline \multirow[b]{2}{*}{$\begin{array}{c}\text { Between } \\
1001 \text { tl } \\
\text { and } 2000 \\
\text { tl }\end{array}$} & Count & 5 & 20 & 35 & 3 & 1 & 64 & \\
\hline & $\begin{array}{l}\text { \% within } \\
\text { monthly } \\
\text { income }\end{array}$ & $7.8 \%$ & $31.3 \%$ & $54.7 \%$ & $4.7 \%$ & $1.6 \%$ & $100.0 \%$ & \\
\hline \multirow[b]{2}{*}{$\begin{array}{c}\text { Between } \\
2001 \text { and } \\
3000 \mathrm{tl}\end{array}$} & Count & 7 & 13 & 30 & 6 & 0 & 56 & \\
\hline & $\begin{array}{l}\text { \% within } \\
\text { monthly } \\
\text { income }\end{array}$ & $12.5 \%$ & $23.2 \%$ & $53.6 \%$ & $10.7 \%$ & $.0 \%$ & $100.0 \%$ & \\
\hline \multirow[b]{2}{*}{$\begin{array}{c}3001 \\
\text { tl and } \\
\text { higher }\end{array}$} & Count & 4 & 10 & 18 & 1 & 1 & 34 & \\
\hline & $\begin{array}{l}\text { \% within } \\
\text { monthly } \\
\text { income }\end{array}$ & $11.8 \%$ & $29.4 \%$ & $52.9 \%$ & $2.9 \%$ & $2.9 \%$ & $100.0 \%$ & \\
\hline \multirow[t]{2}{*}{ Total } & Count & 16 & 43 & 85 & 10 & 3 & 157 & \\
\hline & $\begin{array}{l}\text { \% within } \\
\text { monthly } \\
\text { income }\end{array}$ & $10.2 \%$ & $27.4 \%$ & $54.1 \%$ & $6.4 \%$ & $1.9 \%$ & $100.0 \%$ & \\
\hline
\end{tabular}

$\mathrm{p}<0.05$

When Table 6 is examined, it has been determined whether there is a significant differ- 
ence among the views of athletes regarding which of the following activities they generally prefer in their free times and Chi-Square analysis has been conducted depending on the answers of the athletes according to monthly income variable of the students. Analysis results have showed that there is a significant difference among the activities they generally prefer in their free times according to monthly income variable of the athletes. When the questions responded by the athletes according to monthly income variable of the athletes have been examined, a statistically significant difference has been found $(\mathrm{p}<0.05)$. 


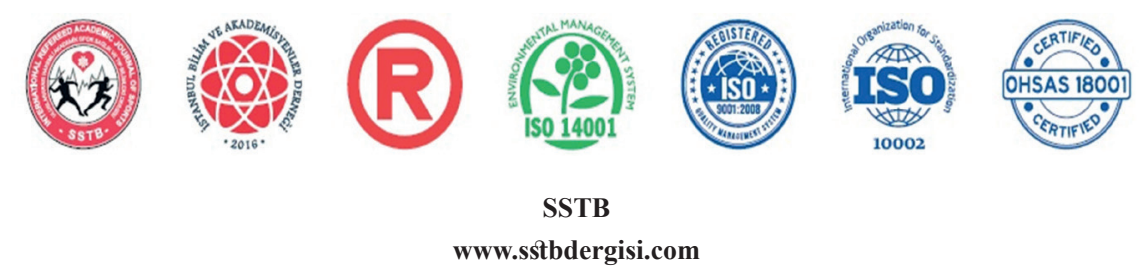

International Refereed Academic Journal of Sports, Health and Medical Sciences

October - November - December Issue 25 Autumn Winter Season Year: 2017

JEL CODE: A220-M490 ID:355 K:129

ISSN Print: 2146-8508 Online 2147-1711

(ISO 18001-OH-0090-13001706 / ISO 14001-EM-0090-13001706 / ISO 9001-QM-0090-13001706 / ISO 10002-CM-0090-13001706)

(TRADEMARK)

(2015/04315- 2015-GE-18972)

Table 7. The Reasons of Choosing Free Time Activities by the University Students Engaged in Karate Do Sports According to Monthly Incomes of the Athletes

\begin{tabular}{|c|c|c|c|c|c|c|c|c|}
\hline \multirow{2}{*}{$\begin{array}{l}\text { Variables } \\
\\
\text { Monthly } \\
\text { Income }\end{array}$} & \multicolumn{6}{|c|}{ What are the reasons of choosing free time activities? } & \multirow[b]{2}{*}{ 要 } & \multirow[b]{2}{*}{ 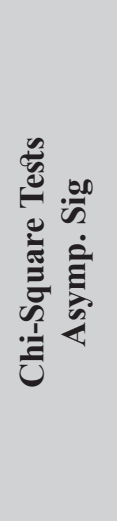 } \\
\hline & & 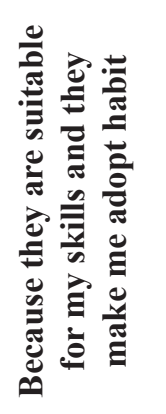 & 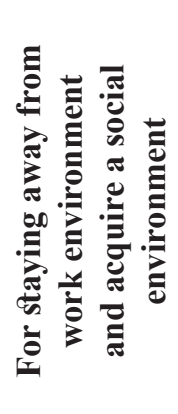 & 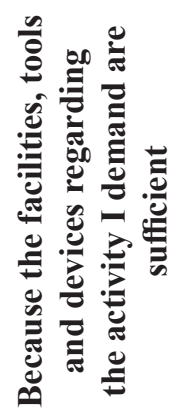 & 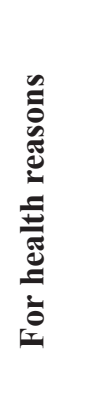 & 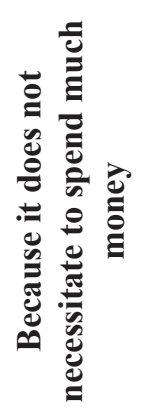 & & \\
\hline \multirow{2}{*}{$\begin{array}{c}\text { Between } \\
550 \mathrm{tl} \text { and } \\
1000 \mathrm{tl}\end{array}$} & Count & 1 & 0 & 0 & 0 & 2 & 3 & \multirow{10}{*}{.000} \\
\hline & $\begin{array}{l}\text { \% within } \\
\text { monthly } \\
\text { income }\end{array}$ & $33.3 \%$ & $.0 \%$ & $.0 \%$ & $.0 \%$ & $66.7 \%$ & $100.0 \%$ & \\
\hline \multirow[b]{2}{*}{$\begin{array}{c}\text { Between } \\
1001 \text { tl and } \\
2000 \mathrm{tl}\end{array}$} & Count & 13 & 35 & 13 & 3 & 0 & 64 & \\
\hline & $\begin{array}{l}\text { \% within } \\
\text { monthly } \\
\text { income }\end{array}$ & $20.3 \%$ & $54.7 \%$ & $20.3 \%$ & $4.7 \%$ & $.0 \%$ & $100.0 \%$ & \\
\hline \multirow[b]{2}{*}{$\begin{array}{l}\text { Between } \\
2001 \text { and } \\
3000 \text { tl }\end{array}$} & Count & 12 & 30 & 11 & 2 & 1 & 56 & \\
\hline & $\begin{array}{l}\text { \% within } \\
\text { monthly } \\
\text { income }\end{array}$ & $21.4 \%$ & $53.6 \%$ & $19.6 \%$ & $3.6 \%$ & $1.8 \%$ & $100.0 \%$ & \\
\hline \multirow[b]{2}{*}{$\begin{array}{c}3001 \text { tl and } \\
\text { higher }\end{array}$} & Count & 13 & 13 & 5 & 3 & 0 & 34 & \\
\hline & $\begin{array}{l}\text { \% within } \\
\text { monthly } \\
\text { income }\end{array}$ & $38.2 \%$ & $38.2 \%$ & $14.7 \%$ & $8.8 \%$ & $.0 \%$ & $100.0 \%$ & \\
\hline \multirow[t]{2}{*}{ Total } & Count & 39 & 78 & 29 & 8 & 3 & 157 & \\
\hline & $\begin{array}{l}\text { \% within } \\
\text { monthly } \\
\text { income }\end{array}$ & $24.8 \%$ & $49.7 \%$ & $18.5 \%$ & $5.1 \%$ & $1.9 \%$ & $100.0 \%$ & \\
\hline
\end{tabular}

$\mathrm{p}<0.05$ 


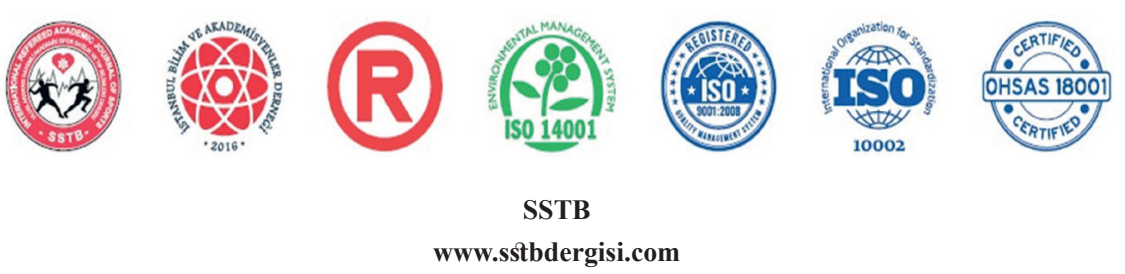

International Refereed Academic Journal of Sports, Health and Medical Sciences

October - November - December Issue 25 Autumn Winter Season Year: 2017

JEL CODE: A220-M490 ID:355 K:129

ISSN Print: 2146-8508 Online 2147-1711

(ISO 18001-OH-0090-13001706 / ISO 14001-EM-0090-13001706 / ISO 9001-QM-0090-13001706 / ISO 10002-CM-0090-13001706) (TRADEMARK)

(2015/04315- 2015-GE-18972)

When Table 7 is examined, it has been determined whether there is a significant difference among the views of athletes regarding the reasons of choosing free time activities and Chi-Square analysis has been conducted depending on the answers of the athletes according to monthly income variable of the students. Analysis results have showed that there is a significant difference among the reasons of choosing free time activities according to monthly income variable of the athletes. When the questions responded by the athletes according to monthly income variable of the athletes are examined, a statistically significant difference has been found $(p<0.05)$. 


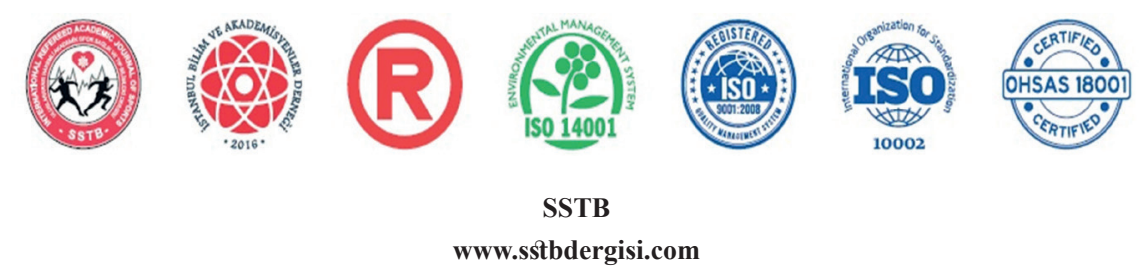

International Refereed Academic Journal of Sports, Health and Medical Sciences

October - November - December Issue 25 Autumn Winter Season Year: 2017

JEL CODE: A220-M490 ID:355 K:129

ISSN Print: 2146-8508 Online 2147-1711

(ISO 18001-OH-0090-13001706 / ISO 14001-EM-0090-13001706 / ISO 9001-QM-0090-13001706 / ISO 10002-CM-0090-13001706)

(TRADEMARK)

(2015/04315- 2015-GE-18972)

Table 8. The Effects of Free Time Activities on the University Students Engaged in Karate Do Sports According to Monthly Incomes of the Athletes

\begin{tabular}{|c|c|c|c|c|c|c|c|c|}
\hline \multirow{2}{*}{$\begin{array}{c}\text { Variables } \\
\begin{array}{c}\text { Monthly } \\
\text { Income }\end{array}\end{array}$} & & \multicolumn{5}{|c|}{ What are the effects of free time activities? } & \multirow[b]{2}{*}{$\begin{array}{l}\bar{\pi} \\
0 \\
0\end{array}$} & \multirow[b]{2}{*}{ 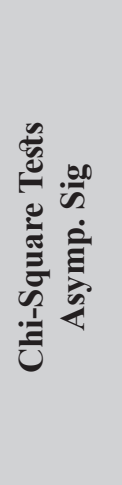 } \\
\hline & & 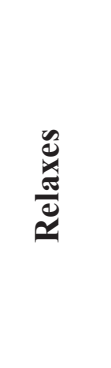 & 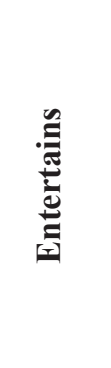 & 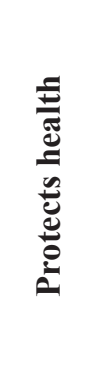 & 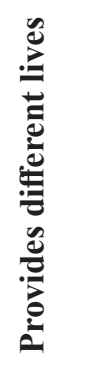 & 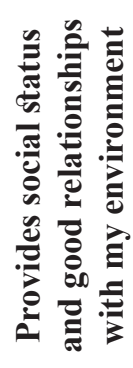 & & \\
\hline \multirow{2}{*}{$\begin{array}{l}\text { Between } 550 \mathrm{tl} \\
\text { and } 1000 \mathrm{tl}\end{array}$} & Count & 1 & 0 & 1 & 0 & 1 & 3 & \multirow{10}{*}{.036} \\
\hline & $\begin{array}{l}\% \text { within } \\
\text { monthly income }\end{array}$ & $33.3 \%$ & $.0 \%$ & $33.3 \%$ & $.0 \%$ & $33.3 \%$ & $100.0 \%$ & \\
\hline \multirow[b]{2}{*}{$\begin{array}{l}\text { Between } 1001 \\
\text { tl and } 2000 \mathrm{tl}\end{array}$} & Count & 2 & 33 & 17 & 6 & 6 & 64 & \\
\hline & $\begin{array}{l}\% \text { within } \\
\text { monthly income }\end{array}$ & $3.1 \%$ & $51.6 \%$ & $26.6 \%$ & $9.4 \%$ & $9.4 \%$ & $100.0 \%$ & \\
\hline \multirow[b]{2}{*}{$\begin{array}{c}\text { Between } 2001 \\
\text { and } 3000 \mathrm{tl}\end{array}$} & Count & 11 & 16 & 20 & 5 & 4 & 56 & \\
\hline & $\begin{array}{l}\% \text { within } \\
\text { monthly income }\end{array}$ & $19.6 \%$ & $28.6 \%$ & $35.7 \%$ & $8.9 \%$ & $7.1 \%$ & $100.0 \%$ & \\
\hline \multirow[b]{2}{*}{$\begin{array}{l}3001 \text { tl and } \\
\text { higher }\end{array}$} & Count & 6 & 15 & 4 & 3 & 6 & 34 & \\
\hline & $\begin{array}{l}\% \text { within } \\
\text { monthly income }\end{array}$ & $17.6 \%$ & $44.1 \%$ & $11.8 \%$ & $8.8 \%$ & $17.6 \%$ & $100.0 \%$ & \\
\hline \multirow[t]{2}{*}{ Total } & Count & 20 & 64 & 42 & 14 & 17 & 157 & \\
\hline & $\begin{array}{l}\% \text { within } \\
\text { monthly income }\end{array}$ & $12.7 \%$ & $40.8 \%$ & $26.8 \%$ & $8.9 \%$ & $10.8 \%$ & $100.0 \%$ & \\
\hline
\end{tabular}

$\mathrm{p}<0.05$

When Table 8 is examined, it has been determined whether there is a significant difference among the views of athletes regarding the ef- fects of free time activities and Chi-Square analysis is conducted depending on the answers of the athletes according to monthly income variable of the students. Analysis results have showed that there is a significant 


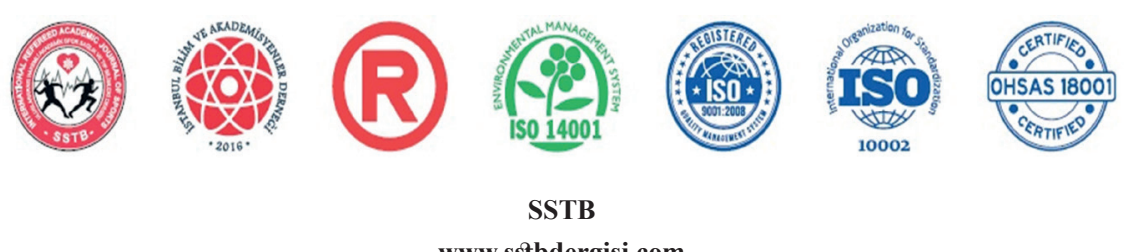

www.sstbdergisi.com

International Refereed Academic Journal of Sports, Health and Medical Sciences

October - November - December Issue 25 Autumn Winter Season Year: 2017

JEL CODE: A220-M490 ID:355 K:129

ISSN Print: 2146-8508 Online 2147-1711

(ISO 18001-OH-0090-13001706 / ISO 14001-EM-0090-13001706 / ISO 9001-QM-0090-13001706 / ISO 10002-CM-0090-13001706) (TRADEMARK)

(2015/04315- 2015-GE-18972)

difference among the effects of free time activities according to monthly income variable of the athletes. When the questions responded by the athletes according to monthly income variable of the athletes are examined, a statistically significant difference has been found $(\mathrm{p}<0.05)$.

\section{DISCUSSION}

In Table 3, it is seen that most of the participant university students, $63.1 \%$ of them, participate in free time activities with their friends. Most of the participants usually allocate their time to free time activities. It is observed that most of the participants generally prefer sports for their free time activities. In the study of Özdilek et al. "Comparison of Participation Reasons and Levels of School of Physical Education And Sports Students Studying in Dumlupınar and Sakarya Universities to Free Time Activities", 19.9\% of 336 students specify that they play sports in their free times (Özdilek vd., 2007: 9). In the study of Göktaş., "A Research Study on Directorate of Tax Administration Personnel's Evaluating their Free Times (Balkesir Sample)", 52\% of the personnel specify that they attend sports activities in their free times remaining from their institution (Göktaş, 2007: 20). This finding shows similarity with the findings in our research.
In Table 3, when the time allocated for daily free time activities of the participants is examined, it is seen that $29.9 \%$ of them spend $1-2$ hours and $25.5 \%$ of them spend 3-4 hours. In the study of Çolakoğlu (2005) titled "A Research on Recreational Activities of Lecturers of University", it has been determined that $40.4 \%$ of these lecturers have 1-2 hours of free-time daily and $75 \%$ of them spend their time by watching TV; however, $16 \%$ of them do sports as a recreational activity. It has also been stated that $47.1 \%$ of the participants cannot participate in recreational activities due to the fact that they do not have enough time and $54.8 \%$ of the participants have stated that they can participate in sports activities in their free-time if the necessary environment and conditions are met.

In Table 3, when the reasons of choosing free time activities of the participants are examined, it is seen that $49.7 \%$ of them choose free time activities for staying away from work environment and acquire a social environment and $27.4 \%$ of them specify that the related institutions do not possess the programs that address to them. In the study of Kandaz and Hergüner, "Examining Types of Utilizing Free Times of Physical Education and Sports Teachers (Sakarya Province Sample), physical fitness and staying healthy take the first place with the rate of $63.8 \%$ as the reason of attending free time activities (Kandaz ve 


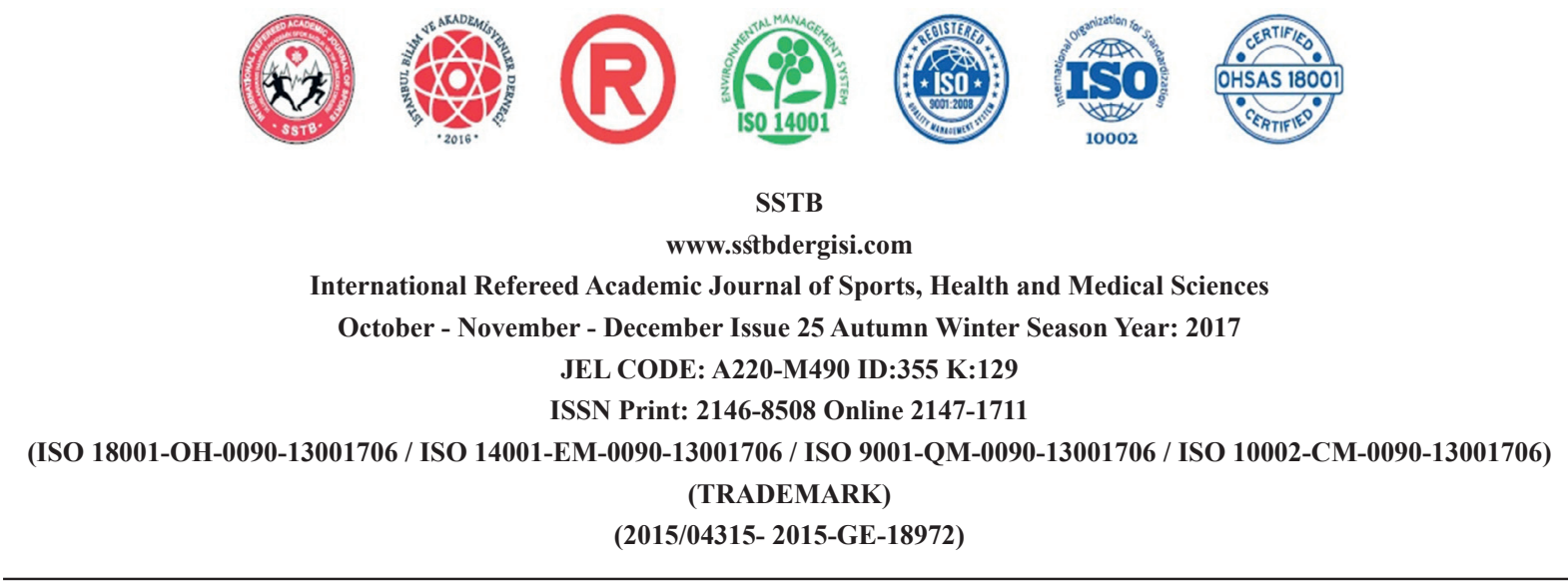

Hergüner, 2006: 6). This finding shows similarity with the findings in our research.

In Table 3, it is observed that among the reasons of not attending free time activities sufficiently, most of the participants choose not having a habit of filling their free times with specific activities. Kandaz and Hergüner, have determined that the reasons for not attending the free time activities which actually they want to attend as the lack of monetary opportunities with $43.6 \%$ and then lack of time for attending the mentioned activities with 30.1\% (Kandaz ve Hergüner, 2006: 6). This finding differs from our research. In Table 3 , it is observed that among the effects of free time activities on the participants, most of the participants choose the entertaining item with a rate of $40.8 \%$. In the study of Kurumlu (2014) titled as evaluation of free-time of the students at 11th grade in Ankara province and their participation in recreational activities in athletic manner, $78.1 \%$ of the participant students have uttered concerning the question how they are affected from recreational activities that these activities are fun. This condition complies with our study.

In Table 4, it is examined whether there is a significant difference among the views of athletes regarding the effects of free time activities by conducting Chi-Square analysis test and it is found a significant difference statistically in the athletes between the ages of 21 and 22 when compared to other age groups regarding the effects of free time activities $(\mathrm{p}<0.05)$.

In Table 5, it is examined whether there is a significant difference among the views of athletes regarding participation type to free time activities in general terms by conducting ChiSquare analysis test and it has been found a significant difference statistically in the athletes possessing income level between 1001 TL and $2000 \mathrm{TL}$ when compared to other income levels regarding participation type to free time activities in general terms $(p<0.05)$.

In Table 6, it is examined whether there is a significant difference among the views of athletes regarding which of the following activities they generally prefer in their free times by conducting Chi-Square analysis. It is seen that the most preferred free time activity by the athletes is playing sports according to income variable of the athletes. It is found a significant difference statistically in the athletes possessing income level between 1001 TL and 2000 TL when compared to other income levels $(p<0.05)$. In the study of Kurumlu (2014), it has been determined that the students living in Ankara have more free-time a week and those living in Polatlı allocate more time to sports in their free-time.

In Table 7, it is examined whether there is a significant difference among the views of 


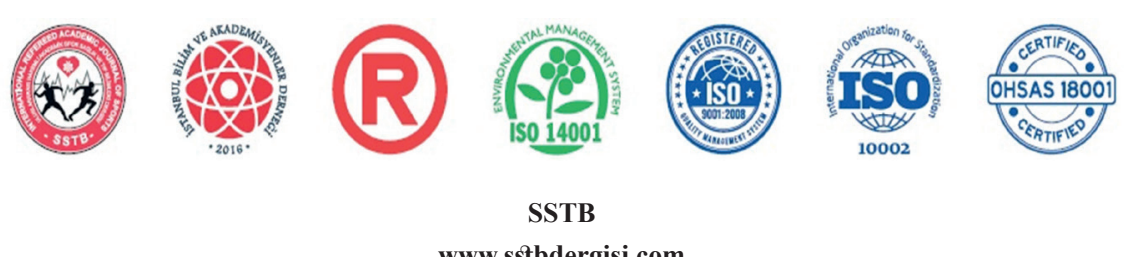

www.sstbdergisi.com

International Refereed Academic Journal of Sports, Health and Medical Sciences

October - November - December Issue 25 Autumn Winter Season Year: 2017

JEL CODE: A220-M490 ID:355 K:129

ISSN Print: 2146-8508 Online 2147-1711

(ISO 18001-OH-0090-13001706 / ISO 14001-EM-0090-13001706 / ISO 9001-QM-0090-13001706 / ISO 10002-CM-0090-13001706) (TRADEMARK)

(2015/04315- 2015-GE-18972)

athletes regarding the reasons of choosing free time activities by conducting Chi-Square analysis. It is seen that the views of the athletes have generally focused on staying away from work environment and acquire a social environment according to income level variable and it is found a significant difference statistically in the athletes possessing income level between $1001 \mathrm{TL}$ and $2000 \mathrm{TL}$ when compared to other income levels $(\mathrm{p}<0.05)$. This condition yields similar results with the study of Gökalp (2007). 6.8\% of the participants have stated that these activities help their friend circle to be extended, $11.8 \%$ of them think that they have obtained different experiences, $16.1 \%$ of them say that they have got rid of work stress thanks to them, $8 \%$ of them have uttered that they have obtained social status and $11.3 \%$ of them have specified that they become involved in interaction and communication with people.

In Table 8, it is examined whether there is a significant difference among the views of athletes regarding the effects of free time activities by conducting Chi-Square analysis. It is seen that the views of the athletes have generally focused on entertaining effect of the activities according to income level variable and it is found a significant difference statistically in the athletes possessing income level between $1001 \mathrm{TL}$ and $2000 \mathrm{TL}$ when compared to other income levels $(\mathrm{p}<0.05)$.
According to the findings stated in the study of Gökalp (2007), $16.9 \%$ of the participants have stated that recreational activities are fun and exciting.

\section{CONCLUSION}

This study examined the applied activities, types of participation to those activities, reasons of preferring those activities and reasons of not preferring the mentioned activities by the university students who were engaged in karate do sports in order to utilize their free times and examined whether the above mentioned factors differed according to the personal features of the students, and with reference to gender, age, place of birth and income level.

It has been found that the difference among the effects of free time activities is statistically significant according to age variable of the athletes. This situation shows that the effects of free time activities on different age-group students are significant. It has been determined that the difference among participation types of the athletes to free time activities in general terms, the most preferred free time activity, reasons of preferring free time activities and the effects of free time activities are statistically significant according to income level variable of the athletes.

When the results of the research are evaluated in general terms, it has been observed that the 


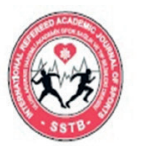

www.sstbdergisi.com

International Refereed Academic Journal of Sports, Health and Medical Sciences

October - November - December Issue 25 Autumn Winter Season Year: 2017

JEL CODE: A220-M490 ID:355 K:129

ISSN Print: 2146-8508 Online 2147-1711

(ISO 18001-OH-0090-13001706 / ISO 14001-EM-0090-13001706 / ISO 9001-QM-0090-13001706 / ISO 10002-CM-0090-13001706) (TRADEMARK)

(2015/04315- 2015-GE-18972)

YILMAZ, S., (2011). Dumlupınar University http://www.karate.gov.tr/?s=karate-do.Erişim Institute of Health Sciences, Department tarihi: 01.07.2016. of Physical Education and Sports Master's Thesis, Kütahya 